\title{
Aikuiskasvatus, sivistys ja työn tulevaisuus
}

\begin{abstract}
1
Hegeliläis-snellmanilaisen sivistyskäsityksen näkökulmasta vapaan kansansivistystyön ja ammatillisen sivistyksen arvojen välinen jännite on keinotekoinen. Aikuiskasvatuksen

tutkimuksen on tartuttava uusien demokraattisten työn ja palvelutuotannon mallien kokeiluun ja teoretisointiin.
\end{abstract}

$\mathbf{y}$ SUOMALAISEN AIKUISKASVATUKSEN 1900luvun suuri ongelma oli vapaan kansansivistystyön ja työelämää palvelevan aikuiskoulutuksen välinen jännite.

Vapaa sivistystyö kehittyi osana 1800-luvun kansanvalistusta ja institutionalisoitui 1900-luvulla työväen-, kansalais- ja kansanopistoiksi sekä opintokeskuksiksi. Niiden tehtävänä oli avata mahdollisuuksia opiskeluun ja itsensä kehittämiseen niille väestöryhmille, jotka jäivät yhteiskunnan eliitille tarkoitetun korkeamman koulusivistyksen ulkopuolelle. Pyrkimys niveltyi yhtäältä kansakunnan rakentamisen prosessiin ja toisaalta työnväenkysymykseen ja maaseudun nuorison sivistysmahdollisuuksiin. Siksi vapaan sivistystyön aatesisältö ei ollut yhtenäinen, vaan siitä kamppailivat muun muassa nationalismin, kristillisyyden ja työväenliikkeen eri aatesuunnat ja ryhmittymät.

Yksi piirre yrityksissä luoda vapaalle kansansivistystyölle omaleimaista teoriaperustaa oli pyrkimys ylittää aatteelliset erot. Samalla kun korostettiin suvaitsevaisuutta ja erilaisen aatesisällön hyväksyntää, vedottiin sellaisiin universaaleihin "vapauden" ja ihmisyyden arvoihin, jotka ylittävät ideologiat ja yhteiskunnallisten ryhmien erityiset pyrkimykset.

Pyrkimys aatteelliseen suvaitsevuuteen ilmenee kansansivistyksen pioneerin Zachris Castrénin perusteluissa vuoden 1929 aikuiskasvatuslaiksi 
(Castrén 1929). Sen sivistysnäkemys irtautui kristillisisänmaallisesta aatesisällöstä ja esitti, että kaikkien aatesuuntien sivistystoiminnalle oli annettava valtion tukea samojen periaatteiden mukaan.

Kansallisfilosofimme J. V. Snellmanin (18061881) sivistyskäsite perustui saksalaiseen uushumanismiin ja erityisesti G. W. F. Hegelin (1770-1831) filosofiaan. Snellman ei pitänyt ajatusta kasvatuksen muuttumattomasta arvoperustasta mahdollisena. Hänen mukaansa sivistyksen ytimenä oli kannan muodostaminen oman aikakauden yhteiskunnan haasteisiin. Esseessään Akateemista opiskelusta Snell$\operatorname{man}(2000$ [1840], 459) toteaa:

"On tarpeetonta sanoa, että [-- jokaisen ajan sivistys on olemassa vain omana aikanaan, niissä yksilöissä, jotka sinä aikana elävät ja vaikuttavat. Jos sivistyksestä tehdään koskaan saavuttamaton päämäärä, jokaisen ajankohdan sivistyksen ulkopuolella oleva, niin kielletään ihmisyys. [--] Edellisestä seuraa, että ihminen voidaan käsittää ajattelevana ja tahtovana subjektina, itsetietoisuutena ainoastaan yhteydessään annettuun perinteeseen ja olemassa olevaan oikeustilaan, yhteiskuntaan.”

Toisen maailmansodan jälkeen aikuiskasvatuksen tehtävään ja aateperustaan vaikutti kolme yhteiskunnallista kehityskulkua. Ensimmäinen oli hyvinvointivaltion rakentaminen 1960-1970-luvuilla ja muun muassa peruskoulun, yhtenäiskoulujärjestelmän ja kirjastolaitoksen kehittäminen koko maata ja kaikkia kansalaisia koskeviksi palveluiksi. Tämä kehitys muutti kansansivistystyön alkuperäistä perustaa, sivistyksen turvaamista työtä tekeville ja koulusivistyksen ulkopuolelle jääneille. Nykyään sivistystyön piiriin ovat tulleet uudet väestöryhmät, kuten työttömät, eläkeläiset tai maahanmuuttajat. Kansalais- ja työväenopistoista ja kansanopistoista on kehittynyt kulttuurisen monimuotoisuuden vaalija, ammatillista sivistystä täydentävä ja rikastuttava instituutio.

Toinen kehityskulku oli työelämää palvelevan aikuiskasvatuksen ja niin kutsutun henkilöstökoulutuksen läpimurto 1960-1970-luvuilla. Se perustui tarpeeseen huolehtia teollistuvan ja palvelujaan kehittävän maan välittömästä työvoimatarpeesta. Esimerkiksi kauppaketjujen ja pankkien koulutuskeskukset järjestivät laajamittaista koulutusta toimihenkilöilleen. Lyhytkurssituksen suunnittelun viitekehyksenä oli behaviorismiin perustuva opetusteknologia.

Toisen asteen ammatillisen koulutusuudistus 1980-luvulla poisti osittain toimihenkilökoulutustarpeen, ja 1990-luvulla yritysten ja julkishallinnon organisaatioiden sisäinen henkilöstökoulutus supistui. Työelämän aikuiskoulutuksen läpimurto herätti kuitenkin laajaa keskustelua aikuiskasvatuksen perusteista ja identiteetistä. Ammatillinen aikuiskoulutus nähtiin vapaan aikuiskasvatuksen sivistysihanteiden kannalta välineellisenä toimintana. Niinpä esimerkiksi aikuiskasvatuksen ensimmäinen professori, filosofi Urpo Harva (1958) halusi rajata sen taloudelle tai hyödylle alistettuna toimintana vapaan sivistystoiminnan ulkopuolelle.

Teollistuvan palveluyhteiskunnan synnyttämä vastakkainasettelu on 2000-luvulla korvautunut uusliberalismin ja kilpailuyhteiskunnan läpimurron synnyttämillä ongelmilla. Tämä kehityskulku toi mukanaan elinikäisen oppimisen käsitteen ja uudisti läpikotaisin sanastoa, jolla puhuttiin yhteiskunnasta taloudesta, työstä ja ihmisenä olemisesta (Kantola 2006).

Analysoin artikkelissani vapaan kansansivistyksen ja ammatillisen ja työelämässä oppimisen välistä jännitettä hegeliläis-snellmanilaisen sivistyskäsitteen näkökulmasta. Viime vuosikymmenien Hegel-tutkimus on osoittanut Hegelin poliittisen teorian edelleen ajankohtaiseksi teoriaksi vapauden, yksilön kehityksen ja sivistyksen historiallis-institutionaalisten edellytyksistä (Smith 1989; Lumsden 2008; Miettinen 2016).

Hegelin teoria sivistyksestä ylittää perinteiset tieteenalarajat. Sen lähtökohtana on yksilön vapaus ja kehitysmahdollisuudet. Yksilö kehittyy moraalisubjektiksi osallistumalla yhteiskunnan instituutioiden toimintaan ja hyväksyy niiden normatiiviset periaatteet omalla järjellään sekä sitoutuu vapaaehtoisesti niiden noudattamiseen, edistämiseen ja korjaamiseen. Sivistys on järkeen perustuvaa yksilöiden sitoutumista yhteisen hyvän harjoittamiseen. Se on yhteiskuntafilosofinen, eettinen, poliittinen ja oikeudellinen teoria inhimillisestä toimijasta (Pippin 2008 , viii). Siksi se on kokonaisvaltainen vaihtoehto kognitiivisen psykologian yksilö- ja tietopainotteisel- 


\section{ABSOLUUTTINEN HENKI}

VIITTAA TIETEESEEN,

TAITEESEEN JA FILOSOFIAAN.

le kehitysnäkemykselle sekä taloustieteen tieto- tai osaamispääoman ja kompetenssin käsitteille, jotka tarkastelevat yksilön kehitystä sosiaalisen menestyksen tai työelämäkelpoisuuden kannalta.

Hegelin teorian näkökulmasta vapaan kansansivistyksen ja työssä tapahtuvan sivistymisen välinen vastakkainasettelu on keinotekoinen. Sen näkemys työn ja työyhteisöjen merkityksestä sivistysprosessissa torjuu työn huonontumisen kysymyksenasettelun yksipuolisena ja kehottaa tarttumaan työn kehityksen emansipatorisiin mahdollisuuksiin vaatimalla, kehittämällä ja kokeilemalla uusia ja vaihtoehtoisia työn ja palvelutuotannon malleja. Se antaa älyllisiä välineitä työn käsitteen laajentamiselle ja kilpailukykypuheen kritiikille.

\section{TEORIA VAPAUDEN JA MINÄN KEHITYKSEN HISTORIALLIS-INSTITUTIONAALISISTA EHDOISTA}

Angloamerikkalaisessa filosofiassa ja politiikan teoriassa kiinnostus Hegeliin on 1980-luvun loppupuolelta lähtien lisääntynyt, ja tulkinta hänen merkityksestään on muuttunut. Filosofi Simon Lumsden (2008) luonnehtii muutosta käänteenä ei-metafyysiseen Hegelin luentaan. 1980-lukua edeltäneessä tutkimuksessa Hegeliä tarkasteltiin absoluuttisena idealistina, joka tutki, miten maailman henki toteutuu historiassa.

'Hengellä' Hegel viittasi luonnosta eroavaan "toiseen luontoon" eli ihmisen, yhteiskunnan ja kulttuurin historiaan. Henki ilmeni kolmessa toisistaan riippuvassa muodossa: subjektiivisena, objektiivisena ja absoluuttisena. Subjektiivinen henki on yksilöön tietoisuuteen sidottu mentaalinen tietoisuus ja tahto. Objektiivinen henki viittaa yhteiskuntaan ja sen instituutioihin, jotka ovat yksilötietoisuudesta riippumattomia mutta vapaan tahdon ja inhimillisen toiminnan "objektivoitunut" tulos. Absoluuttinen henki viittaa tieteeseen, taiteeseen ja filosofiaan, eli ihmisen todellisuutta koskevan ymmärryksen niin ikään kulttuuriksi objektivoituneeseen kehitykseen. Objektiivinen ja absoluuttinen henki olivat olemassa vain subjektiivisen tietoisuuden kautta, mutta niiden kehitys ei ollut palautettavissa siihen (Laitinen 2012, 395-397).

Uudessa tutkimuksessa Hegel nähdään teoreetikkona, jonka teoria yksilönvapauden ja minän kehityksen historiallis-institutionaalisista ehdoista on yhä ajankohtainen. Lumsdenin mukaan $(2008,58)$ Hegelille modernin filosofian ongelma ei ole episteeminen kysymys todellisuuden tiedostamisen mahdollisuudesta vaan kysymys siitä, "kuinka rajallinen olento voi löytää mielekkään paikkansa jatkuvasti liikkeessä olevassa maailmassa”.

Hengen fenomenologiassa (1977) Hegel tutkii vapauden ja siihen kytkeytyvän tietoisuuden kehitystä Euroopan historiassa antiikista moderniin (Lindberg 2012). Lähtökohtana ei ollut yksilö vaan menetetty yhteisöllisyys. Antiikin Kreikan vapaat kansalaiset kuuluivat kaupunkivaltioon, osallistuivat sen päätöksentekoon ja sitoutuivat sen normeihin ja velvollisuuksiin. Yhteys kuitenkin katkesi Rooman valtakunnassa ja feodalismissa. Hierarkkiset valtarakenteet vieraannuttivat ihmistä yhteisöstä.

Hengen kehityshistoriassa Hegel kysyykin, miten yksilöiden menetetty yhteys yhteiskuntakokonaisuuteen voitaisiin rakentaa uudelleen modernissa, kapitalistisessa yhteiskunnassa. Hegel analysoi yksilön ja yhteiskunnan välisen suhteen kehitystä herran ja orjan riippuvuuden kautta. Koska heidän suhteensa ei perustunut vastavuoroiseen tunnustamiseen, kumpikaan osapuoli ei voinut olla vapaa.

Ranskan vallankumous synnytti modernin oikeusvaltion, joka tunnusti kaikkien kansalaisten oikeudet ja poisti säätyyn perustuvat etuoikeudet. $\mathrm{O} i$ keusfilosofiassa (1994) Hegel esitti poliittisen ja yhteiskuntafilosofisen teorian vapauden ja tasa-arvon mahdollisuudesta modernissa maailmassa.

Hegel hylkäsi teoriat ihmisyksilön pysyvistä ominaisuuksia tai olemuksesta historiattomina ja abstrakteina: niiden perustalle ei voinut järjestää moraalia tai yhteiskuntaelämää. Vapaus, moraali ja järki, jotka edellyttävät toisiaan, kehittyvät historiallisesti yhteiskunnallisessa kontekstissa tai institutionaalisessa 
kentässä, jota Hegel kutsui 'siveellisyydeksi' (Sittlichkeit). Siveellisyys tarkoittaa etiikkaa ja moraalia, mutta viittaa saksan kielessä historiallisesti muodostuneisiin tapoihin ja tottumuksiin (Sitte). Angloamerikkalaiset Hegel-tutkijat käyttävät siitä vastinetta ethical life.

Sivellisyys muodostuu perheestä, kansalaisyhteiskunnasta ja valtiosta. Hegelillä yksilön vapaus koostuu osallistumisesta niiden toimintaan (Pippin 2001, 1). Suomalaisen Hegel-tutkijan Markku Mäen sanoin (2012, 210)

"vapautta sanan varsinaisessa merkityksessä ei voi olla olemassa, ellei se ole todellistunut määrättyihin sosiaalisiin ja poliittisiin instituutioihin."

Hegel tarkastelee instituutioita normatiiviselta kannalta. Perheessä toteutuvat rakkauden ja huolenpidon normit. Kansalaisyhteiskunta koostuu markkinoista ja korporaatioista eli ammatillisista yhdistyksistä ja yhteisöistä. Markkinoilla yksilö on vapaa ajamaan omia intressejään ja tyydyttämään yksityisiä tarpeitaan. Ammattiyhteisöissä yksilö kasvaa osaksi erityistä ammattiosaamista ja -etiikkaa sekä osallistuu tietystä yhteiskunnallisesta tehtävästä huolehtimiseen. Valtio taas asettuu yksittäis- ja erityisetujen yläpuolelle ja tekee mahdolliseksi yleisen edun harjoittamisen. Valtion kansalaisina yksilöt luopuvat omista eduistaan yhteisen hyvän saavuttamiseksi.

Amerikkalainen pragmatistifilosofi Robert Brandom $(2007,12)$ luonnehtii Hegelin itsetietoisuuden käsitettä seuraavasti:

"Minänä oleminen on normatiivisten asemien subjektina olemista. Nämä asemat viittaavat sitoumuksiin; se merkitsee kykyä ottaa normatiivinen kanta asioihin, sitoutumista velvollisuuksiin ja niiden täyttämistä.”

Institutionaalisia kenttiä vastaavasti yksilöllä voi olla roolinsa vanhempana, ammatin edustajana sekä kansalaisena, ja hän joutuu ottamaan kantaa roolejaan koskeviin normeihin ja periaatteisiin.

Amerikkalaisen filosofin Frederick Neuhouserin (2000) mukaan Hegelin vapauden käsitteellä on kolme toisiinsa kietoutuvaa ulottuvuutta. Ensimmäinen, henkilökohtainen vapaus, tarkoittaa, että yksilö saa tehdä, mitä tahtoo muiden sitä estämättä tai rajoittamatta.
Liberaalille poliittiselle teorialle ominaisen negatiivisen vapauden luonnollinen pätevyysalue on omistaminen ja omaisuuden hallinta.

Toinen ulottuvuus, moraalinen toimijuus, merkitsee, että yksilö toimii suhteessa muihin sen mukaan, minkä arvioi oikeaksi ja hyväksi. Hän noudattaa esimerkiksi Immanuel Kantin (1724-1804) muotoilemaa moraalilakia, kategorista imperatiivia, tai monia uskontoja yhdistävää kultaista sääntöä, joka kehottaa kohtelemaan muita kuten toivoo itseään kohdeltavan. Hegel kuitenkin katsoo, että niin tärkeitä kuin moraaliperiaatteet ovatkin, ne eivät riitä ohjaamaan ihmisen tekoja arjessa.

Kolmatta vapauden ulottuvuutta, sosiaalista tai institutionaalista vapautta (Sittlichkeit), Hegel kutsuu myös substantiaaliseksi tai konkreettiseksi vapaudeksi. Se toteutuu, kun yksilö osallistuu yhteiskunnan instituutioihin ja sen yhteisen hyvän toteutumiseen.

Sosiaalisella vapaudella on kaksi puolta: Objektiivinen puoli ilmenee siinä, että normatiiviset periaatteet ovat esineellistyneet instituutioihin, kuten universaaliin, kaikille yhtäläisesti tarjottavaan koulutusjärjestelmään, ammatin eettisiin periaatteisiin, perustuslakiin kirjattuihin yksilön oikeuksiin ja demokraattisen valtion toimintaperiaatteisiin. Subjektiivinen puoli taas merkitsee, että yksilö hyväksyy nämä periaatteet omalla järjellään ja sitoutuu niiden noudattamiseen, edistämiseen ja korjaamiseen. Järkeen perustuvaa yksilöiden sitoutumista Hegel pitää kansalaisyhteiskunnan ja valtion elinvoimaisuuden perustana $(1994,210)$ :

"Konkreettinen vapaus taas perustuu siihen, että persoonallinen yksittäisyys ja sen erityiset intressit toteutuvat itselleen (perheen ja kansalaisyhteiskunnan järjestelmässä) täydellisen kehittyneinä ja oikeudellisesti tunnustettuina samalla kun ne siirtyvät yleiseksi intressiksi [--] niin, että ne tunnustavat yleisen intressin omaksi substantiaaliseksi hengekseen ja toimivat tämä intressi tarkoitusperänään. Näin yleinen ei ole voimassa eikä täyty ilman erityistä intressiä, tietämistä ja tahtomista, eivätkä yksilöt elä yksityishenkilöinä pelkästään erityisen intressinsä vuoksi tahtomatta samalla yleistä [--] ja toimivat tietoisesti tämän yleisen päämäärän puolesta.” 
Ammatilliset YhteisöT

OVAT KESKEINEN

TUNNUSTUKSEN

\section{SAAMISEN JA ITSETUNNON}

KEHITYKSEN INSTITUUTIO.

Oma etu ja kokonaisuuden hyvä eivät ole ristiriidassa. Sosiaalisten velvollisuuksien täyttäminen ei rajoita vaan pikemminkin mahdollistaa vapauden toteutumisen. Velvollisuutemme toisia kohtaan vapauttaa meidät yksilöllisyyteen (Good 2006, 37).

\section{TYÖ, TYÖNJAKO JA YHDISTYKSET SIVISTYSPROSESSISSA}

Hegelin teoriassa luova, maailmaa muuttava työ oli keskeinen vapauden ja minän kehitykselle. Hän perusteli käsitystään sekä filosofisesti että yhteiskuntateoreettisesti. Filosofiassaan Hegel pyrki ylittämään kartesiolaisen dualismin, subjektin ja objektin vastakkaisuuden. Toiminnassa ja työssä subjekti ja objekti muuttuvat ja kehittyvät keskinäisessä riippuvuudessa. Yksilö muokkaa ympäristöään sekä itseään, "inhimillistää" ulkoista maailmaa ja "täyttää sen tahdollaan" (Sayers 2003, 111).

Yksilön itsetietoisuus ja kyvyt kehittyvät esineellistymällä tai objektivoitumalla kulttuuriesineiksi, esimerkiksi kirjallisiksi tuotoksiksi, taideteoksiksi, tietokoneohjelmiksi, rakennuksiksi, kodin puhtaudeksi tai kulttuuripalveluiksi. Tuotosten kautta yksilö tulee tietoiseksi itsestään, paikastaan maailmassa ja suhteestaan muihin ihmisiin (Smith 2009). Estetiikan luennoissaan Hegel $(2013,82)$ toteaa, että ihmisellä on tarve

"tunnistaa itsensä siinä, mikä on välittömästi annettua ja ulkoisesti käsillä. Hän toteuttaa tämän tavoitteen muuntamalla ulkoisia olioita, joihin hän painaa sisäisen sinettinsä ja joista hän sitten jälleen löytää omat määreensä.”

Esineellistymisen ohella Hegel luonnehtii työtä vieraantumiseksi, ei-minäksi eli esineeksi tulemiseksi, ja sen ylittämiseksi, kieltämisen kieltämiseksi (Sayers 2003). Työ on siten luovaa toimintaa, jossa yksilö on vuorovaikutuksessa muiden ihmisten ja ympäristön esineiden kanssa ja kehittää samalla kykyjään ja taipumuksiaan. Marx $(1970,160)$ sanoikin Hegelin filosofian suursaavutukseksi sen, että hän "käsittää työn olemuksen ja ymmärtää [--] ihmisen oman työnsä tulokseksi”.

Filosofisen perustelun lisäksi Hegel omaksui Adam Smithiltä ja muilta aikansa poliittisilta taloustieteilijöiltä ajatuksen työnjaon ratkaisevasta merkityksestä sekä taloudelle että yksilön kehitykselle. Keskinäiseen riippuvuuteen perustuvassa taloudessa yksilö ja yhteiskunta ovat vuorovaikutuksessa työnjaon tuloksina syntyvissä ammattiyhteisöissä. Hegel (1994, 180) luonnehti niitä "teoreettisten ja käytännöllisen sivistyksen erityisiksi järjestelmiksi”. Ne ovat keskeisiä kykyjen kehittämisessä, identiteetin rakentumisessa ja panoksen antamisessa yhteiseen hyvään. Psykologi ja kasvatusteoreetikko Jerome Bruner (1915-2016) puolestaan toteaa, että tiedot ja taidot ovat alakohtaisia ja muodostavat 'kulttuurisia työkalupakkeja' (1991, 2). Yksilö hankkii osaamista ja asiantuntemusta jollain tietyllä alalla, eikä yleensä pätevöidy muilla.

Markkinoiden ohella ammatilliset yhdistykset ovat kansalaisyhteiskunnan perusta. Niillä on tärkeä merkitys yksilön kehitykselle. Niissä toimiessaan yksilö "nousee yksilöllisistä tarpeistaan ja intresseistään yhteisönsä jäseneksi, omaksuu sen edellyttämät kyvyt, taidot ja normit ja antaa sen kautta panoksena yhteiskunnan yhteiseen hyvään. Ammatilliset yhteisöt ovat keskeinen tunnustuksen saamisen ja itsetunnon kehityksen instituutio (Hegel 1994, 183):

"Yleisesti ottaen yksilö tekee itsestään todellisuutta vain astumalla läsnäoloon ja tiettyyn erityisyyteen [--] Näin ollen siveellinen asenne on tässä järjestelmässä kunnollisuus ja säätykunnia ja erityisesti pyrkimys tehdä omilla ratkaisuilla, ahkeruudella ja taitavuudella yhden kansalaisyhteiskunnan momentin jäsen, sellaisena pysyä ja tulla tunnustetuksi omissa ja muiden käsityksissä vain näin välitettynä yleiseen.” 
Hegelin mukaan ammatillisilla yhdistyksillä on yksilön kehitykselle neljä toisiinsa kytkeytyvää tehtävää:

1. Erityisten kykyjen ja taitojen, eli "kelpuutetun taitavuuden", hankkiminen ja harjoittaminen

2. Sitoutuminen ja suhteen muodostaminen ammattietiikkaan ja ammatin yhteiskunnalliseen tehtävään

3. Mahdollisuus saada tunnustusta osaamisestaan ja panoksestaan vertaisilta ja kansalaisilta

4. Ammatillisen minäkuvan ja itsekunnioituksen rakentuminen

Lisäksi Hegel pitää ammatillisten yhteisöjen tehtävänä yhteisön ja jäsenten erityisten etujen ajamista esimerkiksi suhteessa valtioon sekä turvan tarjoamista jäsenille työttömyyden tai onnettomuuden kohdatessa. Hegel $(1994,202)$ toteaa, että korporaatioista voi tulla jäsentensä "toinen perhe." Hegelin politiikan teorian tutkija Steven Smith (1989, 236) kiteyttää ammatillisten yhteisöjen merkityksen seuraavasti:

"Nämä välitason yhdistykset ovat eettisen elämän muotoja ja siksi niillä on tärkeä tehtävä yksilön kykyjen kehittämisessä yhteiseen moraalisen kokemukseen ja kansalaisyhteiskuntaan sitoutumiseen."

Hegelin analyysin lähtökohtana olivat 1800-luvun alun ammatilliset korporaatiot. Välitason yhdistysten ja instituutioiden kenttä on sen jälkeen rikastunut tavattomasti. Uusia globaaleja, mutta paikallisesti toimivia, instituutioita ovat esimerkiksi Yhdistyneet kansakunnat (YK) alajärjestöineen, Punainen Risti sekä globaalit vaihtoehtoliikkeet, kuten Amnesty International, Transparency International, Greenpeace ja Friends of the Earth.

Uusia "kykenevöittäviä" instituutioita ovat pohjoismaisen hyvinvointivaltion universaalit koulutus-, kulttuuri-, terveys- ja sosiaalipalvelut, mukaan lukien kansalaisopistot. Pohjoismaissa lähes jokainen aikuinen kuuluu johonkin poliittiseen, sosiaaliseen, ammatilliseen tai harrastusta edistävään yhdistykseen (Miettinen 2013). Uudenlainen instituutio on kotimaassa vuonna 2015 perustettu Me-säätiö, jonka mielestä "maailmassa ei pitäisi olla meitä ja heitä" ja jonka tavoitteena on "vähentää lasten, nuorten ja perheiden syrjäytymistä ja eriarvoistumista Suomessa"(www.mesaatio.fi).

Yhdistykset ovat usein valtion ja kansalaisyhteiskunnan ja jopa perheen välimuotoja, ja siten rinnastettavissa Hegelin 'laajennettuun perheeseen'. Päivähoito nivoutuu lakisääteisenä palveluna kiinteästi perheiden arkeen. Se tuo lapset ja vanhempineen yhteen ja synnyttää parhaimmillaan henkilökunnan ja vanhempien yhteistä, laajennettua huolenpitoa lapsista.

Sosiaali- ja terveysalan yhdistykset ovat yhdistäneet vapaaehtois- ja vertaistoimintaa, jäseniensä oikeuksien puolustamista uusien palvelujen kehittämiseen (Särkelä 2016). Tämä tapahtuu yhteistyössä kuntien kanssa ja sekä Raha-automaattiyhdistyksen että kuntien tuella.

Sosiaali- ja terveysalan yhdistyksiä tutkineen Raija Särkelän (2016) mukaan kilpailuttamislainsäädännön myötä yritykset ovat kuitenkin korvanneet yhdistysten aiemmin tarjoamia palveluja. Sosiaali- ja terveyspalvelujen ostot yksityisiltä palveluntuottajilta lähes kolminkertaistuivat kunnissa 1990-luvun puolivälistä 2000-luvun puoliväliin. (www.oamk. $\mathrm{fi} /$ - eihautal/wwwyrittajyys/kilpailuttaminen.htm, 7.4.2017) Sosiaali- ja terveyspalvelujen uudistuksessa (sote) yhdistysten asema voi vaikeutua nykyisestään.

Yritykset eivät voi täyttää tehtäviä, jotka tekevät yhdistyksistä kansalaisyhteiskunnan perustan: jäsenistä huolehtiminen ja heidän etujensa puolustaminen, vapaaehtoistyö, vertaistuki, koulutuksen ja neuvonnan organisointi sekä aloitteiden teko valtiolle ja kunnille. Yritykset eivät järjestöjen tapaan tunnista tuki- ja palveluverkon ulkopuolelle ja sen aukkoihin jääneiden tarpeita eivätkä tee aloitetta tuen ja palvelujen järjestämiseksi. Ne toimivat luonteensa mukaisesti maksukykyisillä markkinoilla.

Suomessa 1970-1980-lukujen "demokraattista" ammattikäytäntöä ajaneet yhdistykset, kuten Demokraattiset koulutyötyöntekijät (DEMKO), toteuttivat hegeliläis-snellmanilaista projektia yhteisen hyvän turvaamiseksi. Samaa pyrkimystä toteuttaa nykyään esimerkiksi Lääkärit ilman rajoja (MSF). Järjestön tavoitteiden mukaan kaikki ihmiset ovat oikeutettuja läketieteelliseen hoitoon ja heidän tarpeensa ovat 
tärkeämmät kuin kansalliset rajat. Lääkärit halusivat kertoa näkemästään humanitaarisesta hädästä, jotta epäkohtiin saataisiin muutos (www.lakareutangranser. se/suomi). MSF työllistää noin 31000 paikallista ja 2 700 kansainvälistä työntekijää yli 60 maassa. Sen projekteissa hoidetaan muun muassa sotavammoja, ebolaa, hiviä ja aidsia, koleraa, malariaa, tuberkuloosia ja aliravitsemusta sekä annetaan rokotuksia ja terveysvalistusta.

Vuonna 1982 perustettu Psykologien Sosiaalinen Vastuu Ry (PSV) (www.vastuu.fi ) taas ”edistää jokaisen ihmisen oikeutta psyykkiseen ja sosiaaliseen hyvinvointiin" ja hyödyntää psykologien asiantuntemusta. Keinoina ovat muun muassa kriisi- ja traumaterapia.

Valtioiden rajat ylittävät, sosiaaliseen vastuuseen perustuvat järjestöt ilmentävät Hegelin tärkeänä pitämää työnjaon kautta toteutuvaa yleisen, erityisen ja yksityisen ykseyttä. Jäsenet sitoutuvat henkilökohtaisesti (yksityinen) järjestön arvoihin ja tavoitteisiin (kaikkien ihmisten oikeudet) ja toteuttavat niitä erityisen ammatillisen osaamisen kautta erilaisissa, usein kriisialueilla tehtävissä projekteissa. Hegelin (1994, 180) sanoin "vain erityisyyden kautta ajattelu voi saavuttaa todellisuuden ja siveellisen objektiivisuuden".

\section{HEGELIN NÄKEMYS KÖYHYYDESTÄ OSATTOMUUTENA SEKÄ VAPAUDEN JA MINÄN KEHITYKSEN ESTEENÄ}

Sekä Adam Smith että G. W. F. Hegel näkivät työnjaon ja markkinat väistämättömänä kehityksenä, jolla on ristiriitaisia seurauksia. Ensinnäkin ne ovat talouden veturi. Toiseksi työnjako ja mekanisaatio synnyttävät yksitoikkoisia tehtäviä, jotka ehkäisevät ja rampauttavat yksilön kehitystä, tunne-elämää ja sosiaalisuutta. Kolmanneksi markkinat johtavat yhteiskunnan jakautumiseen rikkaisiin ja köyhiin. Hegel (1994, 199) puhuu "alhaison" synnystä:

"Suuri massa vajoaa sen toimeentulon tason alapuolelle, joka säännöstyy itsestään yhteiskunnan jäsenelle välttämättömänä. Kun massa näin menettää oikeuden, kunniallisuuden ja kunniantunnon, joka perustuu omalla toiminnalla ja työllä menestymiseen, syntyy alhaiso. Tällainen tila taas edistää suhteettomien rikkauksien keskittymistä harvojen käsiin.”
Hänen mukaansa $(1994,198)$ ”satunnaiset, fyysiset ja ulkoisiin olosuhteisiin perustuvat seikat voivat syöstä yksilöt köyhyyteen”, mikä johtaa osattomuuteen kansalaisten enemmistön nauttimista palveluista ja eduista $(1994,198)$ :

”Vaikka köyhillä on kansalaisyhteiskunnan tuottamat tarpeet, niin samalla heiltä on siinä riistetty luontaiset toimeentulovälineet ja kumottu perheen laajempi side sukuna. Tämä tila saattaa heidät enemmän tai vähemmän osattomaksi kaikista yhteiskunnan eduista ja taitojen hankintakyvyistä ylipäätään, samoin kuin oikeudenhoidosta, terveydenhuollosta ja usein jopa uskonnon lohdusta jne."

Taloudellinen ja yhteiskunnallinen eriarvoisuus lisääntyy valtioiden välillä. Se lisääntyy myös eri väestöryhmien välillä monissa maailman maissa. Tulo- ja omaisuuserot ovat viime vuosikymmeninä kasvaneet kaikissa OECD-maissa, Suomi mukaan lukien. Lisääntynyt eriarvoisuus on herättänyt huolen yhteiskunnan jakaantumisesta hyvinvoiviin ja huono-osaisiin, joilla ei ole yhtä hyviä mahdollisuuksia osallistua, harrastaa ja kehittää itseään kuin paremmin toimeentulevilla kansalaisilla. Nyrkkeilijä Eva Wahlström kuvaa tilannetta seuraavasti (HS 31.12.2016, A6).

"Tuntuu tekopyhältä sanoa, että kaikilla on samat mahdollisuudet. [--] Näen sen nyrkkeilysalilla. Siellä on monenlaista väkeä: minä tulen perheestä, jolla on aina ollut mahdollisuus ostaa treenivälineet. Ja sitten sinne tulee myös paljon ulkomaalaistaustaisia nuoria, joilla ei ole varaa ostaa edes parin sadan euron suuruista nyrkkeilylisenssiä. Se tarkoittaa, ettei heillä ole lupa kilpailla, joka on minulla ollut aina itsestäänselvyys. Salille tulee myös monia, joilla ei ole varaa edes treenimaksuun tai mahdollisuuksia hankkia treenivälineitä.”

Hegel näki köyhyyden ja osattomuuden johtavan katkeroitumiseen, mutta hänellä ei myöskään ole ratkaisua. Suora tulotuki ei ratkaissut köyhyyden ongelmaa (1994, 199): 


\section{HEGELILLE KÖYHYYS OLI \\ OSATTOMUUTTA YHTEISKUNNAN \\ J ̈̈SENYYDEST $\ddot{A}$.}

”Jos rikkaiden luokalle sälytettäisiin suora vastuu pitää yllä köyhyyteen päätyvää massaa [-- tämä olisi kansalaisyhteiskunnan periaatteen ja sen yksilöiden itsenäisyyden tunteen ja kunniantunnon vastaista, joka perustuu omalla ja työllä ja toiminnalla menestymiseen."

Hyväntekeväisyys, yksittäinen ”sydämen ja rakkauden huomioon ottava" avunanto ei ollut ratkaisu, koska se on (Hegel, 1994, 198) "sinällään että vaikutustensa osalta sattumanvaraista". Siksi yhteiskunnan oli pyrittävä "löytämään puutteenalaisuuden syyt, järjestämään yleiset tukikeinot ja tekemään avustamisen vähemmän tarpeelliseksi".

Hegelin mielestä köyhyys oli vapauden ja minän kehityksen este. Hegel-tutkija Pereira di Salvo (2015, 110) toteaa:

"Hegelille köyhyys on ongelmallista, koska ne jotka joutuvat siihen tilaan, ovat kykenemättömiä toteuttamaan persoonallisuuttaan. Siksi voimme kutsua tätä tilaa sosiaalisesti frustroituneeksi persoonallisuudeksi."

Hänen kollegansa Anastasia Ioannidou puolestaan $(2014,59)$ tulkitsee, että Hegelille köyhyys ei ole ensisijaisesti omaisuuden puuttumista, vaan kyse on "osattomuudesta yhteiskunnan jäsenyydestä ja sen suomien sosiaalisten oikeuksien nautinnasta". Viime aikoina osattomuutta on Suomessa kutsuttu syrjäytymiseksi, ulkopuolelle jäämiseksi. Köyhällä ei ole tunnustetuksi tulemisen yhteisöjä, joissa kehittää itseään, saada tunnustusta ja rakentaa itsetuntoaan.

Ranskalainen taloustieteilijä Thomas Piketty (2015) on tehnyt näkyväksi niin kansakuntien välisen kuin sisäisen eriarvoisuuden lisääntyminen. Pääomatulot ovat kasvaneet viime vuosikymmeninä nopeammin kuin talous, mikä on johtanut pääoman kasautumiseen sekä palkkatulojen ja tulonsiirtojen osuuden pienenemiseen bruttokansantuotteesta.
Oxfram-kansalaisjärjestö arvioi, että lähitulevaisuudessa yksi ihminen omistaa yhtä paljon kuin puolet koko ihmiskunnasta - vuonna 2017 vertausluku on kahdeksan (HS 22.1.2017, B6). Taloudellinen eriarvoisuus on osaltaan ruokkinut pakolaisuutta: elinolojen kurjistuminen ja sodat ovat ajaneet miljoonat ihmiset etsimään turvaa Euroopasta ja muista vauraista maista, jotka ovat sulkeneet tulijoilta ovet, rakentaneet raja-aitoja ja säilöneet heidät usein keskitysleirejä muistuttaviin oloihin.

Vuoden 2016 pakolaisaalto teki Suomessa näkyväksi kansalaisten oikeustajun ja pakolaispolitiikan viranomaiskäytäntöjen välisen ristiriidan. Monet pitävät perheiden hajottamista, niiden yhdistämisen vaikeuttamista, kotoutumisessaan hyvin alkuun päässeiden karkotuspäätöksiä ja paperittomien kohtelua ihmisoikeuksia loukkaavana ja huonosti perusteltuina. Paperittomien ja pakolaisten parissa pitkään työtä tehnyt lääkäri Ari Mönttinen muotoilee tämän tuntemuksen seuraavasti (HS 17.1.2017, B10):

"Suurimmalla osalla näistä ihmisiä ei todellakaan ole mitään, mihin palata, vaikka Suomen lainsäädäntö ja viranomaiset näkevät paljon vaivaa löytääkseen tulkintoja ja porsaanreikiä, mihin heidät työntää. Pakolaiset ovat jättäneet taakseen soraläjän ja ammutuksi joutumisen uhan - tai kantavat ja psyykkisiä ja fyysisiä vammoja mukanaan. [--] Kaikkein järjenvastaisinta on ollut lukea kohtaloista, joissa työnantaja olisi halunnut pitää pakolaisen töissä, mutta oleskelulupa on evätty ja viranomaiset alkavat työllistää itseään maastapoistamisjärjestelyillä. Kuinka paljon Suomen nykyisen lainsäädännön ohjaama viranomaisjärjestelmä käyttäkään aikaa, virkamiesvuosia ja rahaa keksiäkseen keinoja, joilla nämä ihmiset saadaan pois silmistä ja maasta hyödyntämättä heidän kapasiteettiaan ja potentiaaliaan tehdä työtä?”

Mönttinen ehdottaa, että kaikille pakolaisille annetaan välittömästi työlupa ja väliaikainen henkilöllisyystodistus, jotta he pääsevät lamauttavasta joutenolostaan töihin ja uuden elämän alkuun. Maaliskuun ensimmäisenä päivänä 2017 teatterityöntekijät 20 suomalaisessa teatterissa lukivat ääneen Maahanmuuttoviraston (Migri) kielteisiä turvapaikkapäätöksiä, koska kokivat 


\section{P ̈̈̈̈OMATULOT OVAT}

KASVANEET VIIME

VUOSIKYMMENIN $\ddot{A}$

NOPEAMMIN KUIN TALOUS.

niiden perustelut kestämättömiksi ja ihmisoikeuksia loukkaaviksi. Päätökset luettiin sellaisinaan dramatisoimatta, "jotta niiden absurdi sisältö välittyisi kuulijalle kirkkaana" (HS 1.3.2017, B4).

Suomen Punaisen Ristin kansainvälisten asioiden päällikkö Kalle Löövi pitää selvänä, että paperittomista muodostuu Suomeen "osaton köyhäinluokka" (Löövi 2017). Suomen Unicefin ohjelmapäällikön Inka Hautamäen (HS 7.4.2017, B14) mielestä sekä vuonna 2016 solmittu Afganistanin ja Euroopan unionin välinen palautussopimus että Suomen pakolaislakiin vuonna 2106 tehty muutos olivat hätäisesti valmisteltuja ja YK:n lapsen oikeuksien sopimuksen vastaisia. Hän vaatii Suomea noudattamaan joidenkin Saksan osavaltioiden esimerkkiä ja keskeyttämään palautukset Afganistaniin.

Kolme Kirkon perheasianneuvottelukunnan johtajaa nostaa esiin kysymyksen Suomen perheenyhdistämiseen liittyvien menettelytapojen moraalisuudesta (HS 21.4.2017, B14):

"Täysin poissuljettua ja vastoin ihmisoikeussäädösten henkeä on palauttaa kotimaastaan pois muuttaneita ja muulta turvaa hakeneita ihmisiä takaisin kotimaahansa vastoin heidän tahtoaan. Erityisen järkyttävää on, että tällaista menettelyä on sovellettu alaikäisiin lapsiin.”

Kansalaisjärjestöistä nousevat kannanotot ja mielenilmaisut ilmentävät Hegelin keskeistä ajatusta: ilman kansalaisten hyväksyntää valtio ja instituutiot menettävät legitimiteettinsä. Kansalaisten ja yhteisöjen sivistyksellisenä velvollisuutena on palauttaa legitimiteetti vaatimalla muutoksia institutionaaliseen järjestykseen.

\section{TYÖN TULEVAISUUS}

Kriittisen yhteiskuntatieteen suuri kertomus työn kehityksestä ja tulevaisuudesta on työn jatkuva köyhtyminen ja huonontuminen työnjaon, teknologian kehityksen ja uusliberalismin myötä (Siltala 2007). Empiirinen tutkimus ei tätä kertomusta kuitenkaan yksiselitteisesti vahvista (esim. Pyöriä \& Ojala 2016). Raija Julkunen $(2008,320)$ luonnehtii sitä "työn huonontumisen näkökulman pakkopaidaksi", joka kahlitsee ajatteluamme ja mielikuvitustamme. Huononemisnäkemyksen on arvosteltu kuvaavan yksipuolisesti työn muutosta ja vaikenevan sen sisältämistä mahdollisuuksista, Hegelin sanoin (1994, 198) siitä "vapauttavasta momentista, joka sisältyy työntekoon”.

Hegelin dialektinen näkemys korostaa työn kehityksen ristiriitaista luonnetta. Tämä ristiriitaisuus on tullut esiin analysoitaessa uusien teknologioiden käyttöönoton seurauksia. 1980-luvun niin kutsutussa kvalifikaatiokeskustelussa tutkittiin, miten numeerisesti ohjattujen työstökoneiden käyttöönotto vaikuttaisi teollisuustyöhön ja työntekijöiden osaamiseen. Empiirinen tutkimus osoitti, että sen myötä joidenkin yritysten osaamisvaatimukset pienenivät ja toisten kasvoivat, kun työntekijöiltä alettiin edellyttää ohjelmointiosaamista (Toikka 1984).

Nyt yleinen näkemys on, että automatisoiminen kohdistuu ensisijaisesti ammatteihin, jotka sisältävät helposti ohjelmoitavia rutiinitehtäviä, mikä johtaa työmarkkinoiden polarisoitumiseen (Mitrunen 2013, 15):

"Suomessa keskipalkkaisten ammattien osuus kaikista ammateista on vähentynyt vuosina 1995-2008 noin 12 prosenttiyksikköä, kun taas korkeasti koulutetut ja matalasti koulutetut ammatit ovat kasvattaneet osuuttaan.”

Heikkenevän keskiluokan katkeruutta pidetään populismin ja nationalismin kasvualustana.

Pysyväksi muuttuneeseen työttömyyteen on Suomessakin ehdotettu Saksan tapaan matalapalkka- ja osa-aikatyön lisäämistä, mitä tuetaan niin kutsutulla tarjontalähtöisellä politiikalla, lisäämällä työn tarjontaa. Tähän pyritään purkamalla niin sanottuja kannustinloukkuja, leikkaamalla sosiaalietuuksia ja 
työttömyystukia ja tekemällä niistä ehdollisia, esimerkiksi edellyttämällä osallistumista kuntouttavaan koulutukseen tai työpajatoimintaan. Näin osaltaan edistetään kokopäiväisten pysyvien työsuhteiden korvautumista epätyypillisillä osa-aika- ja pätkätöillä. Puhutaan työn prekarioitumisesta ja prekariaatista: prekaari tarkoittaa epävarmaa (Jakonen 2015, 93). Prekariaatti kattaa heterogeenisen joukon itsensä työllistäjiä ja osa-aikaisissa työsuhteissa olevia, joiden työmarkkina-asema ja oikeudet ovat epävarmoja.

Suurtyöttömyys, pysyvästi hidastunut talouskasvu ja toimeentulotukijärjestelmän ilmeiset ongelmat ovat synnyttäneet ajatuksen kaikille kansalaisille samansuuruisena annettavasta perustulosta. Se korvaisi hajanaisen tukijärjestelmän, helpottaisi työn ja sosiaaliturvan yhteensovittamista ja turvaisi pitkäaikaistyöttömille ihmisarvoisen elämän (Perkiö \& Kajanoja 2015). Perustuloa on tulkittu ristiriitaisilla tavoilla (Hiilamo 2016). Sen on nähty pakottavan ihmisiä matalapalkkatyöhön ja luovan uutta alhaisoa. Toisaalta sen on nähty tarjoavan mahdollisuuden työn uudenlaiselle vapautumiselle. Viimeksi mainitun kannan mukaan prekariaatti on pikemminkin uusi voima kuin uhri, ja perustulo lisää työn tekijöiden riippumattomuutta (General Intellect 2008, 289):

"Taattu yhteiskuntatulo, perustulo on uudessa tuotannon tilassa väline, joka luo lakko-oikeutta ja kehittää työn sisältöjä. Se on keino kapitalistisesta arvonmuodostuksesta riippumattomana ajan haltuun ottamiseen ja järjestäytymiseen yrityksen ulkopuolella."

Monet ovat arvioineet, että perustulo voi saavuttaa tavoitteensa vain, jos samalla turvataan työn tarjontaa ja koulutusmahdollisuuksia (Hiilamo 2016). Koska perinteistä kokopäiväistä palkkatyötä ei ole tulevaisuudessa riittävästi tarjolla, työ olisi ymmärrettävä aiempaa monipuolisemmalla tavalla. Uusi työ voisi sisältää esimerkiksi

1. hoivatyötä, kuten työskentelyä vanhushuollossa

2. ympäristön, esimerkiksi metsien, perinneympäristöjen ja puistojen hoitoa

3. kulttuuri- ja liikuntapalvelujen tarjoamista

4. kansalaisjärjestöissä toimimista.
Työt niveltyisivät ja tukisivat julkista palvelutuotantoa. Julkisen vallan olisi kyettävä takamaan näitä töitä jokaiselle kansalaiselle. Työtakuun ideana on, että jokaisella kansalaisella on mahdollisuus tehdä yhteiskuntaa hyödyttävää työtä ja turvata siten kohtuullinen toimeentulo ja osallisuus yhteiskunnassa.

Hegelin käsitys työstä tarjoaa kriteerejä työn käsitteen laajentamiseksi ja työn järjestämiseksi uudella tavalla. Uusien työn muotojen on oltava julkisesti tunnustettuja kuten professioiden, eikä niihin saa liittyä alistavia ja leimaavia kontrollimenettelyjä (Anderson 2009). Niiden on voitava kehittyä työ- ja ammattiyhteisöiksi tai kansalaisjärjestöihin verrattaviksi osaamis- ja arvoyhteisöiksi, joissa yksilö voi kehittää kykyjään, saada tunnustusta ja antaa oman panoksensa yhteiseen hyvään. Edellytyksenä on, että valtio ja paikallisviranomaiset tunnustuvat uuden työn arvon niin lainsäädännössä kuin organisatorisesti ja johtamisessa.

Teoksessaan Democracy of Education John Dewey (1985 [1916], 100) moittii Hegeliä "institutionaalisesta idealismista”, jossa historiallisesti muodostuneet instituutiot ja yksilön vapaus ovat sovitettavissa yhteen ja joka jättää huomiotta instituutioihin esineellistyneet herruussuhteet. Kuitenkin myös Hegel korostaa "molemminpuolista tunnustamisen" periaatteen merkitystä, toisin sanoen vapautta alistavista herra-palvelijasuhteista. Nykyään tämä periaate merkitsee esimerkiksi vapautta nöyryyttävistä hakumenettelyistä, luokitteluista, mielivaltaisesta arvioinnista sekä pakosta ottaa omassa toiminnassaan käyttöön välineitä, menettelyjä ja periaatteita, joita ei pidä järjellisinä ja oikeina.

\section{PÄÄTELMÄT}

Kirjoituksessaan Sivistys ja yleishenki (1991 [1846], 79) Snellman toteaa, että ensimmäinen vaatimus yksilön sivistykselle on, että hän ”perheenjäsenenä, ammatissaan, kunnassaan, kansakunnassaan, ihmiskunnan suurissa kysymyksissä ymmärtää aikansa vaatimukset”.

Aikamme suuria kysymyksiä ovat ilmastonmuutos ja luonnon tuhoutuminen, pakolaisuus, eriarvoisuuden kasvu, nationalismin nousu ja hyvinvointivaltion 
SIVISTYKSEN ON OTETTAVA

\section{KANTAA AIKAMME SUURIIN \\ KYSYMYKSIIN.}

kriisi. Niihin on kaikkien sivistyksestä huolta kantavien instituutioiden omista lähtökohdistaan tartuttava.

Snellmanin sivistyskäsitteen lähtökohtana oli sekä jakamaton ihmisarvo että yleisinhimillinen sivistys (Snellman 2003 [1847], 177):

"Ihmiset oppivat pitämään itseään samaan ihmissukuun kuuluvina, molemminpuolisine velvollisuuksineen ja oikeuksineen, rotuun, heimoon tai kansakuntaan katsomatta."

Hegelin näkemys vapauden ja yksilön kehitysmahdollisuuksien ehdoista koskee kaikkia niitä valtion ja kansalaisyhteiskunnan "kykenevöittäviä" instituutioita, joissa ihmiset sivistyvät kriittiseksi ja vastuullisiksi kansalaisiksi (Miettinen 2013 ja 2014). Näihin kuuluvat koulujärjestelmä, aikuiskasvatuksen laitokset, kirjastolaitos, museot, kulttuuripalvelut, urheiluseurat, työyhteisöt ja ammatilliset yhdistykset ja kansalaisjärjestöt. Kaikki ne joutuvat etsimään tapaansa vastata aikakauden haasteisiin. Toisaalta ne voisivat tehdä sen myös tekemällä nykyistä enemmän yhteistyötä.

Hegeliläis-snellmanilaisesta näkökulmasta vapaan kansansivistystyön ja ammatillisen sivistyksen arvojen välinen jännite on keinotekoinen. Kansalais- ja työväenopistojen perinteinen rooli yhteiskunnan marginaalissa olevien ryhmien sivistystarpeesta huolehtijana on ajankohtainen ja tärkeä.
Se ei ole ristiriidassa työn ja ammatillisten yhteisöjen kautta tapahtuvan sivistysprosessin kanssa.

Aikuiskasvatuksen tehtäväkenttään sopii hyvin toiminta työn ja työorganisaatioiden kehittämiseksi osaamis- ja moraaliyhteisöiksi, joissa työntekijöiden on mahdollista kehittyä ja antaa panoksensa yhteisen hyvän toteutumiseksi yhteiskunnassa. Edellytyksenä on, että tutkimus ylittää kriittisen ja paljastavan näkökulman ja osallistuu vaihtoehtoisten toiminta- ja organisointitapojen teoretisointiin, kehittelyyn ja kokeilemiseen. Lisäksi on yleistettävä kokeiluista oppimisen tuloksia.

Mikäli hyvinvointivaltiomme seuraava vaihe koostuu perustulosta ja yhteiskunnan turvaamasta mutta monimuotoisesta, työstä, sivistystä edistävien instituutioiden väliset erot madaltuvat.

Uudet työtehtävät täydentäisivät julkisia palveluita esimerkiksi vanhustenhoidossa, opetuksessa, kulttuurissa ja ympäristöhallinnossa. Kansalaisten ajankäyttö jakaantuisi eri elämänvaiheissa nykyistä joustavammin työn, opiskelun ja harrastusten kesken, mikä edellyttäisi sivistysinstituutioiden nykyistä tiiviimpää yhteistyötä. Työn ja sivistyksen käsitteitä olisi tulkittava uudelleen, jotta niissä otettaisiin huomioon Snellmanin ilmaisua lainaten "ajan hengen" ja yhteiskuntaelämän muutosten vaatimukset.

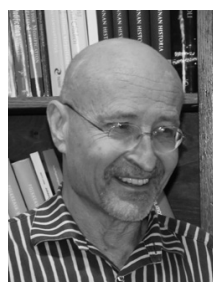

REIJO MIETTINEN

VTT, aikuiskasvatustieteen professori emeritus Kasvatustieteellinen tiedekunta Helsingin yliopisto 
Anderson, S. S. C. (2009). Hegel's Theory of Recognition. London: Continuum.

Brandom, R. (2007). The structure of desire and recognition. Self-consciousness and self-constitution. Philosophy \& Social Criticism 33(1), 127-150.

Bruner, J. (1991). The narrative construction of reality. Critical Inquiry 18(1), 1-21.

Castren. Z. (1929). Valtio ja vapaa kansansivistystyö. Valtioneuvostolle 24 p. heinäk. 1929 annettu mietintö. Helsinki: Kansanvalistusseura.

Dewey, J. (1985 [1916]). Democracy and Education. The Middle Works of John Dewey, Toim. J. A. Boydston. Volume 9. Carbondale \& Edwardsville: Southern Illinois University Press.

General Intellect (2008). Vasemmisto etsii työtä. Helsinki: Like.

Good, J. (2006). A Search for Unity in Diversity. The "Permanent Hegelian Deposit" in the Philosophy of John Dewey. Lanham: Lexington Books.

Harva, U. (1958). Aikuiskasvatus. Johdatus aikuiskasvatuksen teoriaan ja työmuotoihin Suomessa. Helsinki: Otava.

Hegel, G. F. W. (1977). Phenomenology of Spirit. Translated by A. V. Miller. Oxford: Oxford University Press.

Hegel, G. F. W. (1994). Oikeusfilosofian pääpiirteet eli luonnonoikeuden ja valtiotieteen perusteet. Oulu: Pohjoinen.

Hegel, G. F. W. (2013). Taiteen filosofia. Johdatusta estetiikan luentoihin. Helsinki: Gaudeamus.

Hiilamo, H. (2016). Miten perusturvakokeilu onnistuisi? Yhteiskuntapolitiikka 81(3), 343-351.

Ioannidou, A. (2014). The politics of division of labour: Smith and Hegel. Democratization 4(1), 49-62.

Jakonen, M. (2015). Talous ja työ prekaarissa yhteiskunnassa. Teoksessa Mikko Jakonen \& Tiina Silvasti (toim.) Talouden uudet muodot. Helsinki: Into, 92-121.

Julkunen, R. (2008). Uuden työn ja liikkeen äärellä. Yhteiskuntapolitiikka 73(3), 319-325.

Kantola, A. (2006). Suomea trimmaamassa. Kilpailuvaltion sanastot. Teoksessa R. Heiskala \& E. Luhtakallio (toim.) Uusi jako. Miten Suomesta tuli kilpailukyky-yhteiskunta? Helsinki: Gaudemus, 156-178.

Laitinen, A. (2012). Vapauden filosofi. Hegel. Teoksessa P. Koikkalainen \& P.-E. Korvela (toim.): Klassiset poliittiset ajattelijat. Tampere: Vastapaino, 2012, 386-421.

Lindberg, S. (toim.) (2012). Johdatus Hegelin hengen fenomenologiaan. Helsinki: Gaudeamus.

Lumsden, S. (2008). The rise of the non-metaphysical Hegel. Philosophy Compass 3(1), 51-65.

Löövi, K. (2017). Kiihdytysvaihteella ihmisten avuksi. Haastattelu. Telma 1/2017, 32-35.

Marx, K. (1970). Taloudellis-filosofiset käsikirjoitukset 1844. Moskova: Edistys.

Miettinen, R. (2013). Innovation, Human Capabilities and Democracy. Towards an Enabling Welfare State. Oxford: Oxford University Press.
Miettinen, R. (2014). Kykenevöittävä hyvinvinvointivaltio ja koulun kehittämisen haasteet. Kasvatus 45(1), 3-18.

Miettinen, R. (2016). Sivistys kilpailuyhteiskunnassa. Mitä annettavaa Hegelillä on tänään? Kasvatus ja Aika 10(3), 57-75.

Mitrunen, M. (2013). Työmarkkinoiden polarisaatio Suomessa. VATT muistiot 3. www.vatt.fi. (5.3.2017)

Mäki, M. (2012). Absoluuttinen vapaus ja jakobiinien terrori. Teoksessa S. Lindberg (toim.) Johdatus Hegelin Hengen fenomenologiaan. Helsinki: Gaudeamus, 195-223.

Neuhouser, F. (2000). Foundations of Hegel's social theory: Actualizing freedom. Cambridge: Harvard University Press.

Pereira Di Salvo, C. V. (2015). Hegel's torment. Poverty and the rationality of modern state. In A. Buchwalter (ed.) Hegel and Capitalism. Albany: The State University of new York Press, 101-116.

Perkiö, J. \& Kajanoja, J. (2015). Perustulo ja uusi työllisyyspolitiikka. Teoksessa M. Jakonen \& T. Silvasti (toim.) Talouden uudet muodot. Helsinki: Into, 268-285.

Piketty, T. (2016). Pääoma 2000-luvulla. Helsinki: Into.

Pippin, R. (2008). Hegel's Practical Philosophy. Rational Agency as Ethical Life. Cambridge: Cambridge University Press.

Pyöriä, P. \& Ojala, S. (2016). Prekaatin palkkatyön yleisyys: liioitellaanko työelämän epävarmuutta. Sosiologia (53) 1, 45-63.

Sayers, S. (2003). Creative activity and alienation in Hegel and Marx. Historical Materialism 11(1), 107-128.

Särkelä, R. (2016). Järjestöt julkisen kumppanista markkinoiden puristukseen. Sosiaali- ja terveysjärjestöjen muutos sosiaalipalvelujen tuottajina vuosina 1990-2010. Ensi- ja turvakotien liiton julkaisu 40.

Siltala, J. (2007). Työelämän huonontumisen lyhyt historia: muutokset hyvinvointivaltioiden ajasta globaaliin hyperkilpailuun. Helsinki: Otava.

Smith, N. S. (2009). Work and struggle for recognition. European Journal of Political Theory 8(1), 46-60.

Smith, S. (1989). Hegel's Critique of Liberalism: Right in Context. Chicago: The University of Chicago Press.

Snellman, J. V. (2000 [1840]). Akateemisesta opiskelusta. Kootut teokset, Osa 2, 452-476.

Snellman, J. V. (1991 [1846]). Sivistys ja yhteishenki. Teoksessa Valistus, sivistys, kasvatus. Vapaan sivistystyön XXXII vuosikirja, Jyväskylä: Gummerus, 73-82.

Snellman, J. V. (2003 [1849]). Pienten kansojen kaupasta ja teollisuudesta. Litteraturbladet 12, joulukuuta 1849, Kootut teokset, osa 12, 175-189.

Toikka, K. (1984). Kehittävä kvalifikaatiotutkimus. Helsinki: Valtion koulutuskeskus. Julkaisusarja B nro 25. 